\title{
EXPLORING RHETORICAL-DISCURSIVE PRACTICES OF ROUHANI'S PRESIDENTIAL CAMPAIGN AND VICTORY OF HIS PRUDENCE-AND-HOPE KEY: A DISCOURSE OF PERSUASION
}

\author{
Azizullah Mirzaei ${ }^{1}$, Zohreh R. Eslami \\ Fatemeh Safari ${ }^{1}$ \\ ${ }^{1}$ Shahrekord University \\ 8 University str. 8818634141 Shahrekord, Iran \\ ${ }^{2}$ Texas A\&M University, USA \\ 363 Harrington Office Building, 23874 Doha, Qatar
}

\begin{abstract}
Trying to acquire and maintain power, politicians make use of certain rhetorical and linguistic devices to persuade voters in favor of their particular views constructed in the political discourse. The current study was an attempt to investigate Iranian president Hassan Rouhani's use of persuasive rhetorical-discursive devices during his campaign for presidency in 2013. Specific attention was paid to the levels of language that constituted his political discourse through: 1) scrutinizing the level of sound, 2) investigating his selection of lexical elements, and 3) looking into syntactic structures employed to convey political nuances. Additionally, a critical discourse analysis (CDA) approach, drawing upon Fairclough's three-dimensional analytical framework (2010), was adopted to probe the discourse-power relationship in his discourse, on the one hand, and the socio-cultural, religious, and political values underlying the rhetorical devices, on the other. The results revealed that Rouhani's political discourse was embroidered with different rhetorical-discursive devices such as tripartite constructions, repetition in parallel lines, alliteration, and metaphor to influence the public opinion. Moreover, perhaps, using a concise and succinct message, visual symbols, and dynamic metaphors helped him reach out to the audience with an air of emotion and mobilize significant numbers of the electorate for himself.
\end{abstract}

Keywords: Rhetorical devices, CDA, Political discourse, Presidential campaign, Hassan Rouhani

\section{INTRODUCTION}

Although persuasion is inherent to human interaction, it is highly pervasive in the political process (Mutz et al., 1999). As a speech act, persuasion has to do with the intention, act and effect of changing an audience's thinking (Charteris-Black, 2011). Politicians attempt to convince people to change their views using persuasive strategies in their political discourse.

Politics is seen as a struggle for power (Chilton, 2004) and in this struggle politicians try to communicate their plans and policies by providing evidence, persuading the electorate to act in their favor, and convincing them to vote for their plans and thoughts. In this process, language as a social practice (Fairclough \& Wodak, 1997), and the lifeblood of politics (Charteris-Black, 2011) plays a significant role, because it is 
mainly through the social practice of language that politicians construct their identity, negotiating their way through speeches, debates and interviews, and making structurally stable social relationships. Linguistic manipulation is typical of political discourse, and politicians have learned well to obtain power through "the oratorical art of manipulating language for persuasive ends" (Woods, 2006, p.51). In other words, politicians manipulate and frame their ideas and messages in order to better reach their electorates (Bobin, 1988). Messages incorporated in political discourse aim at persuading the audience and affecting their attitudes and beliefs (Vesnic-Alujevic, 2011).

According to Vesnic-Alujevic (2011), persuasion has four interdependent elements including: the speaker, the audience, the message and the way the message is conveyed. Rhetorical devices are tactics intended to engage emotions, shape meaning, and influence the message to be remembered and endorsed by the audience (cf. also Pondy, 1983). Using a rich and wide range of rhetorical strategies, leaders take their audience attention. The language of leadership is constituted through the combined effect of diverse rhetorical strategies (Charteris-Black, 2011). The current research was conducted with the aim to investigate the rhetorical and persuasive linguistic devices employed in the political speech of Iranian President Hassan Rouhani. Furthermore, using a CDA lens, we explain the socio-cultural, religious, and political values underlying the rhetoric evidenced in the dataset.

\section{IRAN'S SOCIO-POLITICAL AND CULTURAL BACKGROUND}

After the Islamic Republic of Iran's Revolution, political campaigns have been a part of Iranian's history and every four years new presidential candidates with different ideas and beliefs and campaign strategies come to the fore. Election campaigns have become larger in scope, relying on a variety of mass media resources (cf. e.g. Al-Ahram Weekly, 2009).

From 2005 to 2013 Mahmood Ahmadinezhad was Iran's president. During his presidency, the Iranian currency, Rial, lost a great deal of its exchange value against the U.S. dollar. Though the collapse of the Iranian currency inside Iran had to do with the sanctions imposed by the US, some considered it largely as the by-product of the government's wrong economic policies, especially the change in the governmental subsidy program which led to domestic inflation and financial instability. The demise of Rial caused a loss in standards of living and domestic poverty (cf. e.g. Al-Ahram Weekly, 2009).

\section{LITERATURE REVIEW}

CDA is one variant of a number of practices that fall under the area of discourse analysis (DA). CDA aims to make obvious the vague connections between discourse practices, social practices, and social structures to the nonprofessional person (Fairclough, 1995b). In van Dijk's (1993, p. 249) sense, CDA examines "the role of discourse in the (re)production and challenge of dominance." Simply put, CDA attempts to bring the link between "linguistic-discursive practices" and "the wider socio-political structures of power and domination" out from the shadow (Kress, 1990, p. 85). Thus, the aim 
of CDA is to go beyond textual analysis to reveal hidden meanings and messages as well as potential social or political interpretation inherent to a linguistic expression, and its effect on the hearers.

What makes CDA different from other forms of DA lies in its attribute of 'critical'. Being critical here implies not taking things for granted; it means being self-reflective, opening up complexity, challenging reductionism, bias and dichotomies, and then based on these processes, making vague structures of power relations and ideologies obvious (Wodak, 2001; also Pennycook, 2001).

Differences in political ethos can be boiled down to different ways of using language (Woods, 2006). In the ideological battle for presidency, the winner is a person whose language, words, messages and promises are more persuasive and appealing. And, this is where critical discourse analysis comes into play to realize what the reality is and how a candidate mobilizes a significant number of voters through the skillful use of language and persuasive rhetorical devices in the most effective way.

Several studies have dealt with the use of different rhetorical devices in political discourse (e.g., Capone, 2010; Cheng, 2006; Rezaei \& Nourali, 2016; Tekin, 2008; Wei, 2000; Wei et al., 2008, etc.). For instance, adopting Lakoff and Johnson's (1980) proposal of metaphor in a case study, Wei (2000) explored the metaphorical usage of campaign slogans in the 1996 presidential campaign in Taiwan. He analyzed the way political ideologies, tactics and strategies were incorporated in metaphors, namely, war, revenge, and a journey in presidential slogans. It was found that there were overlaps and contrasts of metaphorical usage among candidates. Wei concluded that metaphorical usage not only orients candidates' campaign styles but also shapes voters' perceptions of proposed political ideals.

Fairclough (1995) points out that in CDA ideologies, assumed to reside in texts, are not easily discernable, potentially allowing for several different interpretations of the text. Inspired by this assumption, Horváth (2010) attempted to investigate the persuasive strategies employed by Obama in his inaugural address and identify the hidden ideologies in his speech. To link Obama's inaugural discourse with the social processes and to decipher covert ideologies of the text, Horváth performed an ideological analysis. $\mathrm{He}$ simultaneously applied a diachronic method for contrasting 'Obamite' discourse with the 'Bushite' one. Horváth summarized the key ideological components of Obama's speech into several concepts such as pragmatism, liberalism, inclusiveness, acceptance of religious and ethnic diversity and unity to show his persuasive strategies. Horváth argued that, unlike Bush, Obama used personal pronoun 'we' in an inclusive way to show the need for unity which is necessary in the time of national peril.

Drawing upon a Critical Discourse Analysis, Biria and Mohammadi (2012) investigated the potential ideologies underlying George Bush and Barack Obama's discursive strategies and rhetorical devices they employed in their inaugural speeches to express their political views. Through the CDA approach, they found that different discursive strategies were employed by the presidents in achieving their intended goals (e.g., to refute and condemn opposing views, to show that these views are untrue or illegal, and to offer concessions of points to the opposition by answering their questions and offering alternative positions). It was also observed that the first person plural pronoun was frequently used by both presidents in an inclusive way (with higher occurrences in Obama's 
speech), which implied and reinforced national and ideological boundaries. Speaking on behalf of American people, both presidents implicitly exercised their power and corporate ideologies. This way, they put the government and the people in the same group to create unity and solidarity.

Using Moore's (2003) theoretical framework, Rezaei and Nourali (2016) compared the use of persuasive rhetorical strategies in political speeches by the presidents of Iran and the U.S., Rouhani and Obama. The results of their study showed no significant difference between the two presidents' use of persuasive techniques. Both presidents used persuasive strategies (metaphor, parallelism, wordplay, repetition, alliteration, list of three, allusion, etc), but the culture based use of these techniques was evident in their research indicating that language is influenced by the culture.

In recent years, several researchers (Atai \& Mozaheb, 2013; Bonyadi, 2010; Jalilifar \& Alavi Nia, 2012) have analyzed political discourse in the socio-religious context of Iran. For example, Jalilifar and Alavi Nia (2012) used a bottom-up method of analysis to study one of the televised debates of the winners of the American and Iranian presidential elections (Obama and Ahmadinezhad) to investigate the persuasive effects of hedges and boosters as subcategories of metadiscourse markers. They showed that hedges and boosters were utilized to serve different functions cross-linguistically. Due to different experiences, economic status, socio-political concerns, political objectives (in terms of the political parties Obama and Ahmadinezhad were affiliated with), the issues raised during the debates, the debating partner, and the audience they addressed, the two presidents represented two separate worlds. Their study also showed that political debate is a diversified and context-specific genre and cannot be generalized to other settings.

The analysis of political discourse is hardly new. In the discourse-related research conducted so far all around the world, in general, and in Iran, in particular, a great deal of attention has been devoted to political discourse. In spite of the increasing number of research articles on political discourse in Iran over the last decade, certain linguisticdiscursive aspects of the winning presidential campaign discourse and their links to the dominant social, economic, cultural, and political relations, structures, and processes still remain under-researched. Even though political research is on the rise, the critical discourse analysis of political discourse remains largely scant. Adopting an interdisciplinary framework theoretically grounded in CDA as its analytical lens, this study sought to bridge this apparent gap to some extent and account for the rhetorical devices President Hassan Rouhani of Iran employed to appeal to a wider electoral base during his presidential campaign in 2013.

\section{DATA COLLECTION AND ANALYSIS}

From $25^{\text {th }}$ May to $12^{\text {th }}$ June 2013, eight Iranian presidential candidates had the right to use the national TV channels and radio programs presenting their campaign programs, policies, plans and opinions. Data collection methods involved audio recordings of all candidates' presidential campaign programs using a voice recorder. 59 sessions in total were recorded:

- Three live televised debates (held over economic issues, cultural issues, and domestic and foreign policies); 
- TV program "Goftogooye Vijeh Khabari" (special news talk show), IRIB2 (Channel 2 Iran), 27 May 2013;

- TV program “Goftogoo" (talk show), IRINN (News Network), 3 June 2013;

- "Entekhabe Irani” (Iranian Choice), JJ (Jam-e Jam Channel), 30 May 2013;

- "Be Entekhabe Shoma" (With Your Selection), IRIB3 (Channel 3, Iran), 12 June 2013;

- "Ba Doorbin" (With Camera), IRIB1 (Channel 1, Iran), 28 May 2013;

- Rouhani's Documentaries titled "This is the spring that waits behind the winter", 4 and 10 June 2013.

To look into Rouhani's political discourse, all recorded programs were transcribed and checked once more against the video or audio recording for accuracy. Considering the purpose of the study, rhetorical-device-related parts of the collected data were selected for description, categorization, or analysis. Then a critical discourse analysis (CDA) approach, drawing upon Fairclough (2010), was adopted to explore the socio-cultural, religious, and political values underlying Rouhani's choice of specific rhetorical devices. In this framework, discourse is simultaneously seen as (i) a language text (spoken or written), (ii) discourse practice, and (iii) sociocultural practice. The analysis of the text is the study of the language structures produced in a discursive event. The analysis of discursive practice deals with examining the production, consumption, and reproduction of the texts. Finally, the analysis of socio-cultural practice has to do with the investigation of what is happening in a particular socio-cultural context.

\section{RESULTS AND DISCUSSION}

To arrive at a quantitative estimate of the frequency of rhetorical devices in Rouhani's campaign discourse, percentages were obtained. Table 5.1 shows the frequency number and percentage of each category of such devices.

Table 5.1

The frequency and number of rhetorical-discursive devices in Rouhani's discourse

\begin{tabular}{|l|c|c|}
\hline \multicolumn{1}{|c|}{ Rhetorical-discursive device } & Number & Frequency \% \\
\hline Tripartite constructions & 58 & 42.6 \\
\hline Repetition in parallel lines & 35 & 25.7 \\
\hline Alliteration & 12 & 8.8 \\
\hline Metaphor & 11 & 8.1 \\
\hline Personalization & 10 & 7.4 \\
\hline Allusion & 8 & 5.9 \\
\hline Pun & 2 & 1.5 \\
\hline Total & 136 & 100 \\
\hline
\end{tabular}

\subsection{Rhetorical devices in Rouhani's political discourse}

\subsection{Tripartite constructions}

A three-part list is a linked array of juxtaposed items which its final item is often proceeded by conjunction “and” (Wells \& Bull, 2007). As Woods (2006) notes, such a list is employed to suggest wholeness, entirety and unity; it also creates a persuasive 
and effective political rhythm. Rouhani's political discourse was replete with three-part lists. The following extract taken from his speech on IRIB 2 embraces two three-part lists at the level of clause:

khoshhalam dar in si-o-chand sal khattam, masiram, fekram, taghier nakardeh ast. Hichgah efratgar naboodeham na be samt-e rast na be samt-e chap, va emrooz ham omidvaram nemayandegi konam az anhaei ke a'dalat ro doost daran, e'tedal ro doost daran va a'ghlaniyat ro doost daran. "Goftogooye Vijeh Khabari"

I am glad that my line, my path, and my thought have never changed during this 30 years or so. I have never been an extremist toward neither right nor left, and today, I hope to represent those who like justice, like moderation, and like rationality.

Rouhani represented a list of three related entities including "my line", "my path", and "my thought" that have not changed over the years (after the Revolution), to signal his stable character and viewpoints. Using three similar qualities _ "khat" (line), "masir" (path), and "fekr" (thought) — and listing them one after another the speaker intends to increase the persuasive force of the utterance.

The same style is also echoed through a list of three important qualities of the electorate he wants to represent: "I hope to represent those who like justice, like moderation, and like rationality". The air of wholeness, completeness, and unity (Woods, 2006) of these tripartite structures promote a more lasting and powerful effect on audience.

Below is another tripartite structure from his Documentary:

Amadeh-am baraye nejat-e eghtesad-e Iran va ta'amol-e sazandeh ba jahan, ehyay-e akhlagh-e jame'e dolat-e tadbir o omid ra tashkil deham. (Documentary)

I have come to establish the government of prudence and hope to rescue Iran's economy, dialogue constructively with the world, and revive society's ethics.

Rouhani cleverly criticizes the current situation and Ahmadinezhad's policies by using tripatriate structures conveying the need to rescue the economy, constructive dialogue with the world, and reviving the society's ethics. Therefore, by addressing people's concerns, awakening their hopes, and making populist promises, he stood on the right emotional level with audience constructed his popularity among them. Moreover, he contrived to persuade the audience to believe that, by standing firmly behind him, they will achieve a bright future.

Rouhani's speech occurs in a period of financial crisis for Iran. It is a period in which Iran has accumulated an enormous financial debt with the persistent weakening of the currency, in addition to the economic crisis, partly due to Ahmadinezhad's fundamentalist stance and open opposition to the U.S. and ensuing sanctions on Iran. These issues are hinted at in Rouhani's speech. Rouhani presents himself as the person who has come to rescue the economy and open the door to other countries with constructive dialogue and wisdom. He establishes an authorial self, builds his own authority and agency and takes ownership of them, using the first person pronoun 'I' and the non-modal present tense.

Rouhani's success lies in rationally guessing what kind of issues and attitudes the represented person would like to have addressed. A successful political leader will 
be successful in representing an electorate only if s/he is successful in addressing the issues that matter to the electorate. As stated by Capone (2011), the notion of 'representing the electorate' is taken very seriously in Anglo-American countries, where the represented often write letters to their representatives in order to speak of a certain problem and where politicians often reply in writing to the letters they receive.

Another example of the tripartite structure at the sentential level, taken from the Documentary, is the following:

Agar mikhahid 'ezat o shokooh o majd o'azamat be hameh Iranian bargardad, rial-e Irani be jaye aval-e khod bargardad, gozar name Irani be ehteram-e khod bargardad, paye sandoog-e 'ara beshtabid. (Documentary)

If you want honor, glory, magnificence, and greatness to go back to all the Iranians, the Iranian Rial to go back to its former strength, the Iranian passport to go back to its former glory, hurry to ballot boxes.

Again, the power of three, this time nesting inside the sentence structure, has been used to unify items. If you want $\mathrm{x}, \mathrm{y}$, and $\mathrm{z}$ to happen, then make it happen, i.e., hurry to ballot boxes.

It is also worth mentioning that the imperative mode used in the hurry to ballot boxes, positions subjects differently. Rouhani is represented as a speaker who feels very re-assured in suggesting the ballot box for change. In Fairclough's (1989) view, the systematic asymmetry in the distribution of imperative mode between Rouhani and the addressee is important here for understanding the nature of their relationship. Rouhani is making a direct request, indicating a position of power, but at the same time signifying solidarity and inclusiveness.

Perhaps, one of the most recurrent issues in Rouhani's presidential campaign was the promise to change the status quo. The value of Iranian passport was another issue Rouhani had against the current government, referring specifically to the fact that a growing number of countries required the Iranian nationals to be fingerprinted upon arrival, which was largely perceived as humiliating. The measure was also widely seen as a direction sequence of Ahmadinezhad's harsh rhetoric in foreign policy. As a critique of Ahmadinezhad's government, Rouhani voiced his displeasure with the situation and pledged to lead Iran out of the crisis, by using ideologically loaded lexical choices (e.g., prudence, dialogue, hope, moderation).

In Fairclough's (1989) view, ideology is pervasively present in language and what is ideologically significant about a text is its lexical choice and semantic load. Rouhani chose strong and emotionally loaded lexical terms, for persuading his audience to go to ballot boxes.

Ideologically loaded vocabulary is evident in words including honor, glory, magnificence, greatness, and respect. According to Fairclough (1989), ideologies are closely attached to language since using language is the commonest form of social behavior. What appears to be the case here is an ideological clash between the moderate and extreme lines-Rouhani's government vs. Ahmadinezhad's-as evidenced in Rouhani's discourse (I have come to substitute the moderate line for the extreme line). 


\subsubsection{Alliteration}

Alliteration, a particular play on sounds, was used in Rouhani's speech. The function of alliteration is to enhance the impact and persuasiveness of the message. Below is an example taken from one of his speeches:

Barnameh-ye dolat-e tadbir-o omid ta'amol-e sazandeh ba jahan ast, va na taghabol, va jay-e in taghabol ra ta'amol khahad gereft. "Entekhabe Irani".

The government of prudence and hope's plan is to dialogue constructively with the world, and not to confront, and this confrontation will be replaced by dialogue.

In the above alliterative utterance loaded on a contrast, the plosive " $\mathrm{t}$ " is repeated several times. Alliteration is a rhetorical device used for getting attention and making the message memorable. The distinct and noticeable nature of alliterative plosive " $t$ " captivates the audience's auditory senses resulting in evoking their emotion, due to the existence of a connection between the sense of hearing sounds and feelings (cf. Obeng \& Hartford, 2008).

In addition, the alliteration mechanism not only accentuates the beauty of the language via the repetition of the plosive " $t$ " run-in through Rouhani's discourse but also acts as the music with which his thoughts are expressed and shown to be unified (Woods, 2008). It also suggests harmony and clarity in his thinking process and calls the attention to the core of his message (i.e., the government of prudence and hope's plan, which is "ta'amol-e sazandeh ba jahan ast, va na taghabol," meaning, to dialogue constructively with the world, and not to confront) that might not have the same emphasis otherwise.

Here is another example of using consonants to embed the message in the audience memory:

Barname sheshom bayad be zendegi-e mardom behbood bebakhshad, sabat bedehad, aramesh bedehad be jame'e. "Be Entekhab-e Shoma".

The sixth program should improve people's life, stabilize the society and make it relax.

Or:

Kasi hagh nadarad dar magham-e e'lan-e aslah salahiat-e salehan ra zir-e so'al bebarad. (Documentary)

No one in charge of publicizing the most honorable has the right to question the authority of honorables.

The repetition of the sibilant "s" across the sequence of successive words has made an alliterative phrase. The sound play here can make the message more effective. Furthermore, the experiential value of this negative sentence is the main way of differentiating what is not the case in reality form. Considering the experiential value related to the negation, it should be noted that negation has to do more with intertextuality and the intertextual context of the text (Fairclough, 1987).

\subsubsection{Political sloganizing: Rouhani's political brand}

Rouhani's political campaign reached a high point with the usage of a unique and memorable slogan. The effective use of a short, memorable and quotable sound bite (Charteris-Black, 2011) with a concise and snappy message (Woods, 2006) helped him 
to create a clear and memorable slogans (e.g., Dolat-e tadbir-o omid: The "government of prudence and hope").

Nianxi (2009) argues that "effective slogans should be free from logical fallacy, easy to remember, and rationally demonstrable" (p. 109). Accordingly, Rouhani's slogan was easy to comprehend, pronounce, and remember. Pronouncing "dolate tadbir o omid" is easy, since the tongue can move from one position to the next one easily, e.g /to/, /tæ/, /ro/, /o/. It is also appealing to the sense of hearing (Nianxi, 2009), and short enough to be said in one breath.

Moreover, the audiences are not persuaded by chance but through the speaker's underlying purposes and ability to communicate the deliberate intention of persuasion effectively through rhetoric (Charteris-Black, 2011). In this vein, Rouhani's slogan homes in on two key words (prudence and hope), "without any intervening grammar" (Woods, 2006, p. 26) e.g. 'my government is ...'.

Furthermore, Rouhani's election campaign slogan acted as the backbone of his campaign and a highly influential factor to make the Iranian society aware of his basic ideology and views. As the most convenient and practical means of mobilizing people, slogans and catchphrases play an important role in political discourse because they publicize and market the attitudes and beliefs of a candidate contesting an election (Nianxi, 2009). Politicians frequently resort to attracting the audience's attention by using impressive and memorable slogans that succinctly sum up what their campaign is all about. Rouhani's unique way of motivating the electorate masses reflected through his inspiring slogan, influenced voters' electoral choices. Another noteworthy aspect of this carefully crafted message is its relevance to the socio-economic conditions of Iran, which assured Rouhani a victory at the polls. This catchy phrase had an appeal to the electorate and enlivened Rouhani's campaign.

\subsubsection{A man of people}

Giving a touch of informality to his discourse, Rouhani tried to show himself as sharing interests with the ordinary people as shown in the following example:

Man doos daram sedaye shajarian ra, ham doos daram, ham goosh mikonam. (Documentary)

I like Shajarian's voice, I both like it and listen to it.

Mohammad-Reza Shajarian is one of the most celebrated Iranian classical singers, who has enormous popularity among Iranians especially owing to his well-known masterpiece "Our Lord" (Rabanna). For many years, Iranians have broken their daily fast during the Ramadan month when Shajarian's Rabanna was aired on the state TV. It is important to note that Shajarian has banned the Iranian public TV and radio networks from broadcasting his songs after the 2009 uprising against Ahmadinezhad's government and was in return barred from holding any concert in Iran. By strategically referring to Shajarian's name, amongst all the other classical singers in Iran, Rouhani contrived to make the musician's numerous fans confident that he is "just one of us"; and to establish himself as "a man of people". Moreover, Rouhani resonated with his audience and showed to have shared common interests. The informal discourse style in his 
speech and using Shajarian's name, as Woods (2006, p. 56) asserts, allows Rouhani "to slide into a slightly more man of people accent, this way he enacted and negotiated his identity in his talk (Ivanic, 1997, cited in Fairclough, 2010) through creating a 'discoursal self'. To put it differently, Rouhani drew upon socially available discourses and subject positions to create a discoursal self in his talk when he identified himself with the interests and values of ordinary populace.

The government's ban on airing Shajarian's famous Rabanna song provoked a public outcry demanding broadcasting the song (especially during the holy month of Ramadan). The public's dissent was addressed by Rouhani to voice support for Shajarian's works in order to channel his own discontent with such constraints and introduce himself as a man of shared interests with the audience he was addressing. Rouhani's discourse skillfully shifted from a formal political discourse to an informal discourse of the lay public as necessary.

\subsection{The use of typical lexical entries in Rouhani's political discourse}

In politics, careful and selective use of words is of paramount importance, and the selection of words is both a matter of policy and strategy (Woods, 2006). Using polysemous words such as puns have strategic effects in political discourse. The following section illustrates some of the lexical strategies Rouhani used.

\subsubsection{Pun and metaphor}

Hameh kar ba tadbir emkanpazir ast va in tadbir ma ra be sahele omid khahad resand "Ba Doorbin" (Documentary)

Everything is possible with prudence, and this prudence will get us to the hope shore.

Prudence, used repeatedly by Rouhani, could mean "prudence as wisdom", and "the government of prudence (and hope)". There is an interrelationship between these dual meanings which can play a significant role on the impact level of the message. Additionally, 'metaphor' is the phenomenon by which somebody talks and thinks about something in terms of something else (Semino, 2008). New phenomena are understood by applying existing known concept schemes to the unknown. Therefore, metaphor is a conceptual mapping from one semantic source domain to another (Lakoff \& Johnson, 1980). Rouhani compared prudence with ship to metaphorically implying that his prudence can save Iranians from the emerging socio-political catastrophe just like a rescue ship saving those drowning in a stormy sea. This metaphorical slogan could serve a powerful role in evoking emotional support from the voters and convince them to accept his course of action (voting for him).

According to Charteris-Black (2011), to understand the persuasive force of political language it is essential to understand the systematic nature of metaphor choices. He considered a metaphor as an incongruous linguistic representation that influences opinions and judgments through persuasion. Metaphor is indirect and relies on a conflict between what is said and what is meant. In order to reconcile this conflict the hearer search for a relevant interpretation (Charteris-Black, 2004). 
As a successful political leader, he is skillful in controlling a variety of linguistic resources (Duranti, 2006), as illustrated below:

Dar zemestan-e farhang, siasat, va eghtesad hastim keh hava bas najavanmardaneh sard ast. (Documentary)

We are in the cultural, political and economic winter that the weather is so ruthlessly cold.

Both metaphor and allusion are used in this excerpt. Allusion is a literary device which activates two texts simultaneously. It is a tacit reference to another literary work and activates the independent elements from the evoked text (cf. Hylen, 2005). In the example above, the function of allusion falls in the meta-textual domain. Rouhani metaphorically made a comparison between winter and the current cultural, political and economic situation in terms of severe coldness. Here, the analogy acts as a powerful rhetorical device in that it compares the unfamiliar and abstract concepts of culture, politics and economy to the familiar coldness of winter. Besides, through a dynamic allusion, and without direct quotation, he evokes the prominent Iranian poet Mehdi Akhavan Sales, and his well-known poem, "Winter" and links the audience to the past events. The familiar phrase "the weather is so ruthlessly cold" borrowed from Akhavan Sales's poem, Winter, is an allusion used to skillfully highlight the existing problems in the field of culture, politics and economy.

By using allusion and metaphor, he signified the cold weather of winter in terms of current plight and misery that has come about as a consequence of the previous fundamentalist's policies and, at the same time, he pointed to the frozen atmosphere of Akhavan-e-Sales's era. Here, not only did he depict the current problems in terms of a great poet's words (intertextuality), but he also extended the situation to the historical times when the government of prime minister Mohammad Mosaddegh was toppled on 19 August 1953 by the UK- and US-backed coup d'état. Being affected by 1953 frigid atmosphere, Akhavan Sales versed his well-known poem "Winter". His poem symbolically represents the chilly and frozen atmosphere of those days. The choice of this metaphor (Winter) and connecting it to the heroic past, Mosadegh era and Akhavan Sales's poem, has a possible ideological significance and reveals his moderate political ideology covertly. Humming "the weather is so ruthlessly cold", Rouhani aimed to bring to light the current cold situation especially economic situation resulting from wrong policies and deeds of Ahmadinezhad's government and also unfair sanctions imposed by the U.S. against Iran. The same device echoes in the example below:

In baharist ke dar post-e zemestan mandast. (Documentary)

This is the spring that waits behind the winter.

Here, instead of using a blunt tone against Ahmadinezhad's government, Rouhani criticized the current situation subtly. Whilst winter is associated with coldness and frigidity, spring has to do with renewal and growth; spring is also used metaphorically as the beginning of better times ahead. It is common knowledge that spring follows winter, and it implies that Rouhani's victory will ensue; therefore, the persuasive force of the message is maximized. 
In Charteris-Black's (2004) and Goatly's (1997) view, the metaphorical language as a rhetorical device is a matter of pragmatics; the hearer is invited by the speaker to take part in an interpretation to create a meaning through coping with the conflict between what is said and what is meant.

Moreover, Ferrari (2007) argues that metaphor can be used as an important tool for persuasion in a text; it has the potential to act as a privileged cognitive tool for abstracting and constructing discourse strategies. In line with this, Rouhani used an imagebased rhetorical strategy to criticize Ahmadinezhad in his presidential campaign, to evoke powerful emotional reactions and to persuade the electorate to vote for him. The figurative representation of Ahmadinezhad's government and the new one through the skillful choice of natural events enhance the persuasive power of the message. Rouhani describes the reality in a persuasive definition and value-laden term. Using these persuasive definitions to represent the new government and the status quo has a significance importance in argumentation (Fairclough \& Fairclough, 2012). Such value-laden terms with their positive and negative emotional connotations help arguer achieve certain and desired conclusions. Defining the new government which awaits winter paved the way to claim that the government of prudence and hope will be established: spring will come and it is a fact of nature. According to Fairclough and Fairclough (2012), a rhetorically motivated representation including metaphors should not only be considered as an isolated feature of a text but also an argumentative function which steers the argument toward a certain conclusion.

However, the idyllic depiction of the perfect spring day is incomplete without taking into consideration the wider picture. What did the winter leave behind? There are some straws and dirty patches, some waste beneath the thawed ice that should be removed. It takes time for the splendor of the new season to shine forth, the trees to reach their peak blooming, the blossoms to burst into colorful flowers. Extending the metaphor further, Rouhani could also implicitly refer to what will be left by the sitting government.

The next extract exemplifies the employing of a metaphorical definition in an argument, showcasing another important rhetorical strategy employed by Rouhani: he deliberates and weighs the reasons, and finally makes a practical judgement about what ought to be done using metaphorical language. For example:

Masale farhang o asibhaye ejtemaei yeki az mohemtarin masael-e ejtemaei va meli mast. Enqelab-e ma asasan yek enqelab-e farhangi boud az ebteda va emrouz moteasefane ba'd az 35 sal dar zamine farhang anche mardom-e ma bayest shahed bashand, nistand. Enqelab-e ma enqelab-e nour boud, enqelab-e akhlaq boud ... hame asibhaye ejtemaei ba baresi ke ma dar markaz-e tahqiqat-e esteratejic kardim, taqriban rou be afzayesh bude dar salhaye akhir, baraye che? Baraye inke un mabnaye farhangi asib dide. Rahkar chist? Che kar bayad bekonim baraye in hame moshkelat? Man dar mian-e anva'e rahkarhaye mokhtalef mohemtarin rahkar ra tamarkoz-zodaei midanam. Ta zamani ke farhang-e ma doulatist, masael-e ma hal o fasl nakhahad shod. Ta zamani ke ma be jaye ta'miq be tarvij bepardazim masael-e ma hal o fal nemishavad. Ta zamani ke be donbal-e kamiyat bashim va har rouz amar bedahim, amar touklid konim, ya na aslant amar vaqei bashad, ama donbal-e asar bakhshi nabashim, masael-e ma hal o fasl nakhahad shod. Chera hame karha be dast-e 
doulat ast, dorost ast ke doulat dar hoze farhang bayad siasatgozar bashad, bayad nezarat bekonad, bayad hemayat bekonad va avalin hemayatash ham shafafiyat dar moqararate, avalin hemayatesh ham ijade fazaye amn dar jame'e ast. Ama dare in-e hal bayad ma kar ra be saheban-e asli ashab-e honar vagozar konim va doulat hami-e unha bashad.... Nabayad be nahadhaye rasmi ektefa konim. Eshkal-e ma in ast ke farhang ra hamanand-e abshari midanim ke bayad bar sar-e mardom baz konim. Farhang haman cheshmehaye joushani ast ke dar nahad-e mardom hast va bayad sharayet ra amade konim ta hame az farhang-e dorost dar jame'e estefade konnand .... Ma agar br farhanf qavam dehim movafaq shodeim...

Culture issue and social problems are of our most important social and national issues. Our revolution was primarily a cultural revolution from the beginning, and today unfortunately after 35 years people do not see what they should observe in the field of culture. Our revolution was light revolution, was ethics revolution... Given our investigation in strategic studies center, all social problems have been nearly increased in recent years. Why? Because that culture basis has damaged. What is the strategy? What should we do for all these problems? Amongst different types of strategies I consider decentralization as the most important one. As long as our culture is public, our problems will not be resolved. As long as we engaged in deepening instead of promoting, our problems will not be resolved. As long as we are after quantity and represent statistics every day, produce statistics, or no statistics is real at all, but we are not after effectiveness, our problems will not be resolved. Why are all works held by the government? It is true that the government should be the policy maker in the field of culture, should monitor, should support, and its first support is clarity in regulations, its first support is creating a secure environment in the society, but we should delegate work to the original owners of the art, and the government should support them...

...We should not confine ourselves to official institutions. Our fault is that we see culture as a waterfall to be opened over the people's head. Culture is those gushing springs embedded in the people's nature, and we should prepare conditions so that all people can use the right culture in the society... if we give consolidation to the culture we will succeed...

The extract above illustrates a form of deliberation. After describing the context, Rouhani proposed the explicit question of 'what should we do?'. Then in a monologic deliberative process the same as a deliberation in a multi-agent context, he reasoned practically, pretended that he has weighed different options and now has arrived at the right and the most important course of action i.e., decentralization ('Amongst different types of strategies I consider decentralization as the most important one').

Deliberation as a rhetorical strategy involves different options' critical examination (Fairclough \& Fairclough, 2012). This text analysis revealed that Rouhani represented the alternative choices in such a way that avoided an actual deliberation formation. In this monologic text, Rouhani represented the alternatives in a negative way, implying that was no real choice at all. This does not happen in a real face to face dialogue. In Fairclough and Fairclough's (2012) view, deliberation which restricts consideration of alternative options and steers the argument toward one possible conclusion is an ideological deliberation.

Rouhani's argument appears to be rhetorically effective, even though he does not provide much evidence for his claims. In developing his argument, he does not offer any 
alternative options, nor is it always clear how he arrived at the conclusions he is putting forward. In Searle's (2010) view giving people reasons for action that they do not otherwise have is a common way of exercising power. Similarly, Fairclough and Fairclough (2012) assert that power manifests itself as ideology when the existence of alternative possibilities for action is obscured. It seems that Rouhani is utilizing precisely this rhetorical strategy here, warning that 'our problems would not be resolved' if the implementation of the current policies continues.

Furthermore, some statements with an in-built negative meaning (e.g. 'social problems', 'unfortunately people do not see what they should observe in the field of culture', 'no statistics is real', 'our problems will not be resolved', 'we are not after effectiveness', 'that culture basis has damaged', etc.) Rouhani uses to describe what he sees as cultural problems in the society and recommends specific actions. Therefore, is-statements have been presented in a way that ground ought-statement in what is the most important strategy to be considered ('What is the strategy? What should we do for all these problems? Amongst different types of strategies I consider decentralization as the most important one').

Another interesting issue is employing a metaphorical definition to propose a claim. Charteris-Black (2004) believes that metaphorical concepts can contribute to making arguments more persuasive. After representing the circumstances and weighing the options, Rouhani re-describes the reality in a persuasive definition and value-laden term. Using persuasive definitions ('Culture is those gushing springs embedded in the people's nature') to represent the world has a significant importance in argumentation (Fairclough $\&$ Fairclough, 2012). Such a value-laden term with its positive emotional connotation help the arguer achieve certain and desired conclusions. Defining culture as gushing springs which have been embedded in the people's nature paved the way to the claim that 'delegating the work to the original owners of the art (people themselves)' is the right action. According to Fairclough and Fairclough (2012), a rhetorically motivated representation including metaphors should not only be considered to be an isolated feature of a text. Such a representation has also as argumentative function which steers the argument toward a certain conclusion.

\subsubsection{Personalization}

As an argumentative discourse, political discourse includes practical argumentation deployed in response to political problems (Fairclough \& Fairclough, 2012). This extract is a good example of practical argumentation.

Ma dar Iran-e ba azamat o bozorgi zendegi mikonim ke daraye manabe besyar qani-e phiziki va madi va nirouye ensani-e arzeshmand o faal ast. Keshvari ke dar hasastarin noghte jahan gharar gerefte ast, keshvari ke daraye geopolitic va geostrategic vije khod dar mantaqe ast. Shahrahe shomal be jonoub ast. Dovomin manbae gaz-e jahan o naft-e jahan ast. Ama chera mardom-e ma dar moshkelat-e maishati bashand? Moshkel kojast? Moshkel az modiriyat aqaz mishavad, moshkel az tasmimat-e fardi aqaz mishavad, moshkel as adam-e mashverat aqaz mishavad... Che mikhaham begouyam? Mikhaham begouyam mardom-e aziz o bozorgvar bayad edare keshvar edare elmi bashad, bayad hokmrani, hokmrani-e shayeste bashad. Bayad estefade az nokhbegan anjam shaved, bayad ba shafafiyat ba mardom harf 
zad, bayad moshkelat ra ba mardom dar mian gozasht, bayad amarha daqiq bashad ta ma betavanim az pich-e tarikhi ke maqam-e moazam-e rahbari farmoudand be khoubi obour konim va betavanim hamase eqtesadi va siasi ra biafarinim... Ma bayad hameh marakez-e tolidi ra be fa'aliat-e kamel-e sad dar sad beresanim va in kar emkanpazir ast dar barnameh modavan-e man. "Ba Doorbin"

...We live in the big and great Iran which has very rich physical and material resources and valuable and active human resources The country which is located on the most sensitive point of the world, the country which has its special geopolitics and geostrategic in the area the highway of north to south, the second gas and oil recourses of the world, but why our people have living obstacles, where is the problem? The problem begins from the management; The problem begins from individual decisions; The problem begins from lack of consultation ... what I want to say, I want to say: dear and honorable people, the country management should be scientific management, the governance should be a worthy governance, we should employ elites, we should talk to people in a transparent way, we should talk about problems with people, the statistics should be accurate so that we can pass well the historical turn the Supreme Leader said and create the epic saga of political and economic... We should bring all the production centers into full $100 \%$ operation, and it is possible in my systematic plan.

"Where is the problem?" is a rhetorical question posed to make certain points. By posing such a question Hassan Rouhani does not actually expect to receive any answer. He only wants to emphasize the existence of problems. Here there is a list of "where is the problem", presented as three key sources in which problems are rooted, including: the former president's "management", "individually made decisions", and "lack of consultation" nested in the sentence structure. Positioning himself as a critic of the administrative status quo, Rouhani tried to put the blame for these "problems" on Ahmadinezhad's mismanagement. In fact, "individually made decisions" and "lack of consultation" are relatively synonymous. It seems that "individually made decisions" has been rephrased into "lack of consultation" to assure that the audience have realized where the problem lies.

Rouhani's focus is primarily on concrete obstacles and on the representation of management, individual decisions, and lack of consultation as the origin of the problem that exist as a fact. The argument for action here starts from a description of the context of action and the goal which is informed by values. This arguments starts from a question which is implicit here ("what should we do?"), then based on the analysis of the current circumstances and the expected goals, the courses of action are proposed, and the consequences of such actions discussed.

The inclusive use of the first-person plural pronoun ' $W e$ ' enables Rouhani to achieve inter-subjectivity and speak on behalf of the whole nation while simultaneously making an implicit authority claim for himself. His conversational public tone was followed by a personal one. He effectively uses the inclusive 'we' at the beginning and then switches to the singular possessive pronoun ('my systematic plan') to take ownership of his responsibility and to evoke a competent and confident identity of himself as the future president. 


\subsection{Sentence structure in Rouhani's political discourse}

\subsubsection{Parallel lines}

Parallelism is the application of similar syntactic structures and gives harmony and power to the speech (Biria \& Mohammadi, 2012, p. 1298). Below is an example of parallelism used in Rouhani's speech. Parallelism can include a contrasting of the two opposing ideas given in adjacent phrases. A parallel structure drawn upon sentences is at work to group items together and to unify them to reflex the notion of related elements through the following parallel lines:

Barnameh-e dolat-e tadbir-o omid ta'amol-e sazandeh ba jahan ast, va na taghabol, va jay-e in taghabol ra ta'amol khahad gereft.

The government of prudence and hope's plan is to dialogue constructively with the world, and not to confront, and this confrontation will be replaced by dialogue.

An antithesis parallelism is drawn across an alliterative utterance in which a contrast is made between the paralleled elements (Woods, 2006). What the government of prudence and hope plans to do is contrasted with what it plans not to do, and "taghabol" (confrontation) is contrasted with "ta'amol" (dialogue). Through a parallel structure, the elements are grouped, and the audience is engaged in comparing the two ideas (confrontation with dialogue).

In Goffman's idea of participation frameworks and production formats a particular instance of speech can be broken down into animator, author and principal. As the ultimate animator, author and principal, Rouhani represented the conflict between the moderation party's political views or agenda and that of the fundamentalist party.

In terms of text distribution, Rouhani uses already existing texts to create his speech. In Fairclough's (2010) view, for any particular text there is a set of other relevant texts and voices which are potentially incorporated into the text. Fairclough observes the relationships among different discourses and relates text analysis with social structure. Intertextuality opens up difference by bringing other voices into a text. Resorting to intertextuality, Rouhani embedded the fundamentalist's voice into the text implicitly. This intertextuality accentuates the dialogicality of a text (Fairclough, 2003), the dialogue between Rouhani's voice as the author of a text and another opposing voice. As can be seen, confrontation and dialogue are in marked contrast to each other. Focusing on the current government's foreign policy, he replaced Ahmadinezhad's wording by his ideologically contrastive assertion i.e., this confrontation will be replaced by dialogue. The following example is a parallelism which was used to group and contrast different ideas: "strong prudence not beautiful sentences" with "action not claims", and "objective truth not advertising movies" with "resistance in insight and providence not the colorful posters and lustrous headquarters". The paralleled structures and ideas combine to create a unified sense and powerful impact.

Faghat az mardom mikhaham keh na be jomalat-e ziba keh be tadabir-e mohkam, na be edea'aha keh be amalkardha va na be filmhay-e tablighati keh be vagheiyat-e e'ini na be setadhay-e por zargh o bargh o posterhaye rangi balkeh be esteghamat dar nazar va ayandehnegari ra'i dehan. ( $3^{\text {rd }}$ debate) 
I only ask people to vote for strong prudence not beautiful sentences, action not claims, and the objective truth not advertising movies, strength in insight and foresight not the colorful posters and lustrous headquarters.

Rouhani discreetly invited the audience to assume that the strong prudence, reliable action and strength in insight and foresight are his qualities as a president and reflected in his policies.

\subsection{The visual symbol in Rouhani's political discourse}

Last but by no means least, acting in a creative way, Rouhani signified his metaphorical political message simply by a familiar visual object, a key, implying that everything is locked, and he has the key to resolve Iran's problems. Using the key symbol, as a visual interpretation of his campaign objectives, he tried to reach out to all sectors of the society, especially the grassroots, influencing their views and helping them more easily envisage his campaign's central message.

Beyond words, visual representations and symbols can be employed by political leaders to affect the electorate's emotions. Rouhani's presidential campaign symbol was a "key" he pledged it would solve Iran's problems, namely, failed nuclear negotiations, the collapsing currency value, and the sanctions. The key represented a metaphor to make the audience hopeful about practical solutions for Iran's future. It enabled him to embody his message in "hope" and "prudence", and it was a major boost for him to reach out to voters in the society through this visual symbol. The strength of ideology expressed by Fairclough (1989, p. 208) as "the camera doesn't lie" (Fairclough, 1989, p. 208). The key allowed political advertising to more effectively create a world which the audience may be lead to inhabit and played a significant role in Rouhani's victory.

\section{CONCLUDING REMARKS}

In this study, we examined Iran's $11^{\text {th }}$ presidential campaign discourse and looked into Rouhani's use of rhetorical and persuasive linguistic devices which enabled him to present his political ideology and, potentially, had a positive role in his subsequent election victory. Linguistic-discursive elements of political discourse were analyzed in a bottom-up style to build up a picture of how these elements might have contributed to Rouhani's political discourse characterization. A CDA approach, drawing upon Fairclough (2010), was adopted to explain the socio-cultural, religious, and political values underlying the rhetoric documented in the dataset.

The main purpose of political speeches is "primarily persuasion rather than information or entertainment" (Dedaić, 2006, p. 700). These speeches are considered as purposeful interaction between the political figure and the electorate, in which the speaker's goal is to influence the electorate to accept the speaker's views and support him/her with their ballots. To be able to achieve their goals, politicians use a variety of rhetorical strategies to construct a trustworthy image of themselves, responding to the concerns of their voters, and showing inclusiveness and solidarity with them.

Our findings indicate that Rouhani's political discourse was spiced up with different rhetorical devices, aiming at making the audience accept his views, thoughts, 
and policies. He criticized the current socioeconomic and cultural situation of Iran by virtue of different devices to embed his messages deep into the electorate's mind i.e., Iran has many problems and the blame is on the existing government mismanagement and wrong policies. Being considered as a critic of the current situation, and a person who emphasized to put an end to it, Rouhani was able to increase his chance to win the election. The central pillar of his success was his political performance. He separated himself from the current situation and then challenged it and gained the support of those who said no to the existing situation.

Moreover, Rouhani's campaign could possibly be seen as a social struggle at the institutional level, and as a more general struggle at the societal level between moderates and fundamentalists. Rouhani's points of view which were represented all over his speeches, debates, interviews, messages, and slogans were his administration's standpoints. He did not deliver them as an individual, but rather as a representative of a certain party, the moderate party. Rouhani's goal was more than trying to influence the electorate and their knowledge about what is best for them to do to get rid of the current plight and misery ensued from the fundamentalist party's wrong policies. He aspired to put an end to the status quo by enforcing his agency and the assertive tone and structures in his speeches.

The findings can be of interest to those interested in discourse analysis. Having a critical attitude offers a new perspective on language, which considers language use as a questionable and problematic issue, and reflects social and ideological processes and constitutes a resource to act upon those processes. However, it is worth mentioning that the area of CDA, in general, and political discourse analysis, in particular, is a vast area, and this case study is by no means a complete account of how CDA can be employed to dissect the different types of discourses that have the manipulative power to marginalize some and empower others for further research it is suggested to investigate the upcoming presidential election in 2017 , to compare Rouhani's campaign strategies with findings of this study and potentially trace the shift in his next campaign cornerstone. Researchers can also do a comparative study between the moderate ideology advocated by Rouhani's campaign speeches and fundamentalist's ideology advocated by Ahmadinezhad's speeches.

(C) Azizullah Mirzaei, Zohreh R. Eslami, Fatemeh Safari, 2017

\section{REFERENCES}

Al-Ahram Weekly online. 18 -24 June 2009. Issue No. 952.

Atai, M., \& Mozaheb, M. (2013). The representation of Iran's nuclear program in British newspaper editorials: A critical discourse analytic perspective. International Journal of Society, Culture, and Language, 1(2), 15-33.

Biria, R., \& Mohammadi, A. (2012). The socio pragmatic functions of inaugural speech: A critical discourse analysis approach. Journal of Pragmatics, 44(10), 1290-1302.

Bobin, J.P. (1988). Le marketing politique: Vendre L'Homme et L'Idée [Political marketing: How to sell a man and an idea]. Paris: Milan Media. 
Bonyadi, A. (2010). The rhetorical properties of the schematic structures of newspaper editorials: A comparative study of English and Persian editorials. Discourse \& Communication, 4(4), $323-342$.

Capone, A. (2010). Barack Obama's South Carolina speech. Journal of Pragmatics, 42(11).

Charteris-Black, J. (2004). Corpus approaches to critical metaphor analysis. Hampshire/New York: Palgrave Macmillan.

Charteris-Black, J. (2011). Politicians and rhetoric: The Persuasive power of metaphor. Basingstoke: Palgrave Macmillan.

Chilton, P. (2004). Analyzing political discourse. Theory and practice. London: Routledge; 2964 2977.

Cheng, M. (2006). Constructing a new political spectacle: Tactics of Chen Shui-bian's 2000 and 2004 inaugural speeches. Discourse and Society, 17(5), 583-608.

Fairclogh, I. \& Fairclough, N. (2012). Political discourse analysis: A method for advanced students. London and New York: Roultedge.

Dedaić, M.N. (2006). Politeness speeches and persuasive Argumentation'. In Keith Brown (ed.) Encyclopedia of Language and linguistics, Vol. 9. Amsterdam: Elsevier, 700-707.

Duranti, A. (2006). Narrating the political self in a campaign for U.S. Congress. Language in Society, $35,467-497$.

Fairclough, N. (1989). Language and Power. London: Longman.

Fairclough, N. (1995). Media discourse. London, New York, Sydney: Edward Arnold.

Fairclough, N. (2003). Analyzing discourse. London: Routledge.

Fairclough, N. (2010). Critical Discourse Analysis: The critical discourse analysis. London: Longman.

Fairclough, N. \& Wodak, R. (1997). Critical discourse analysis. In T.A. Van Dijk (Ed.), Introduction to discourse analysis, 258-284.

Ferrari, F. (2007). Metaphor at work in the analysis of political discourse: investigating a preventive war persuasion strategy. Discourse and Society, 18(5), 603-625.

Goatly, A. (1997). The language of metaphors. London and New York: Routledge.

Goffman, E. (1981). Footing. In E. Goffman (Ed), Forms of Talk. Philadelphia: University of Pennsylvania Press, $124-159$.

Horváth, J. (2010). Critical discourse analysis of Obama's political discourse. Retrieved July 4, 2013, from http://www.scribd.com/doc/39586848/.html

Hylen, S. (2005). Allusion and meaning in John 6. Berlin: De Gruyter GmbH.

Ivanic, R. (1997). Writing and identity: The discoursal construction of identity in academic writing. Amesterdom: Benjamins.

Jalilifar, A., \& Alavi Nia, M. (2012). We are surprised; wasn't Iran disgraced there? A functional analysis of hedges and boosters in televised Iranian and American presidential debates. SAGE, $6(2), 135-161$.

Kress, G. (1990). Critical discourse analysis. Annual Review of Applied Linguistics, 11(1), 84-99.

Lakoff, G., \& Johnson, M. (1980). Metaphors we live by. Chicago, IL: Chicago University Press.

Mutz, D., Sniderman, P., \& Richard, B. (1999). Political Persuasion and Attitude Change. Ann Arbor: The University of Michigan Press.

Nianxi, X. (2009). Political Slogans and Logic. Diogenes 56 (1), 109-116.

Obeng, S.G., \& Harford, B. (2008). Topics in political discourse analysis. (Eds). Hauppauge, N.Y.: Nova Science. 
Pennycook, P. (2001). Critical Applied Linguistics. Mahwah, New Jersey: Lawrence Erlbaum.

Pondy, L. (1983). The role of metaphors and myths in organization and the facilitation of change. In L. Pondy, P. Frost, G. Morgan, \& T. Dandridge (Eds.), Organizational symbolism. Greenwich, CT: JAI Press, 157-166.

Rezaei, S., \& Nourali, N. (2016). Language and power: The use of persuasive techniques in Iran and U.S. president speeches. Journal of Language Teaching and Research, 7(6), 1203-1209.

Semino, E. (2008). Metaphor in discourse. Cambridge, New York: Cambridge University Press.

Tekin, B.C. (2008). The construction of Turkey's possible EU membership in French political discourse. Discourse \& Society, 19(6), 727-763.

Van Dijk, T.A. (1993). Principles of critical discourse analysis. Discourse and Society, 4(2), 249-83.

Vesnic Alujevic, L. (2011). Communicating with voters by blogs? Campaigning for the 2009 European Parliament elections. Discourse \& Communication, 5(4), 413- 428.

Wei, L., Lu, L., \& Ahrens, K. (2008). Ideological influence on BUILDING metaphors in Taiwanese presidential speeches. Discourse \& Society, 19(3), 383-408.

Wei, J.M. (2000). An analysis of the metaphorical usage of campaign slogans in the 1996 presidential campaign in Taiwan. Journal of Asian Pacific Communication, 10(1), 93-14.

Wells, P., \& Bull, P. (2007). From politics to comedy: A comparative analysis of affiliative audience responses. Journal of Language and Social Psychology, 26(4), 321-342.

Wodak, R. (2001). What CDA is about: A summary of its history, important concepts and its developments. In R. Wodak and M. Meyer (Eds.), Methods of Critical Discourse Analysis. London: Sage, $1-13$.

Woods, N. (2006). Describing discourse: a practical guide to discourse analysis. Hodder Arnold: London.

\section{Article history:}

Received: 05 September 2016

Revised: 14 October 2016

Accepted: 18 November 2016

\section{For citation:}

Azizullah Mirzaei, Zohreh R. Eslami, Fatemeh Safari (2017). Exploring Rhetorical-Discursive Practices of Rouhani's Presidential Campaign and Victory of his Prudence-and-Hope Key: a Discourse of Persuasion. Russian Journal of inguistics, 21 (1), 161-182.

\section{Bio Note:}

Azizullah Mirzaei, DSc, Associate Professor of Applied Linguistics at English Department at Shahrekord University (Iran). Research interests: Pragmatics, Discourse Theory, Discourse Analysis, Intercultural Communication. Contact information: e-mail: fazizullah@yahoo.com

Zohreh R. Eslami, DSc, Professor at Department of Teaching, Learning and Culture at Texas A\&M University at Qatar (Doha). Research Interests: Cross-Cultural Pragmatics, Cultural Issues Related to Second Language Teaching, Learning, and Assessment Developmental Pragmatics, ESL/EFL Teacher Education. Contact information: e-mail: zeslami@tamu.edu

Fatemeh Safari PHd Student. Research interests: Second Language Acquisition, Pragmatics, Discourse Analysis, Discourse Theory, Intercultural Communication. Contact information: e-mail: f_19safari@yahoo.com 


\title{
ДИСКУРС УБЕЖДЕНИЯ: \\ РИТОРИЧЕСКИЕ И ДИСКУРСИВНЫЕ ПРАКТИКИ В ПРЕЗИДЕНТСКОЙ ИЗБИРАТЕЛЬНОЙ КАМПАНИИ РУХАНИ И ПОБЕДА ЕГО ПРИНЦИПА БЛАГОРАЗУМИЯ И НАДЕЖДЫ
}

\author{
Азизулла Мирзаи', Зохрэ Есламиㄹ, Фатима Сафари ${ }^{1}$ \\ ${ }^{1}$ Университет Шахре-Корд \\ 8 University str., 8818634141 , Шахре-Корд, Иран \\ ${ }^{2}$ Техасский университет A\&M в Катаре (США) \\ 363 Harrington Office Building, 23874, Дoxa, Kamap
}

\begin{abstract}
В попытке приобрести и сохранить власть политики используют в своих выступлениях определенные риторические и языковые средства, чтобы привлечь избирателей на свою сторону. Настоящее исследование явилось попыткой изучения риторических и дискурсивных средств убеждения, использованных Хасаном Рухани в предвыборной кампании на пост президента Ирана. Особое внимание было уделено изучению языковых средств различных уровней, составивших основу его политического дискурса. В центре внимания оказались:1) фонетические особенности его речи, 2) выбор лексических средств, 3) особенности синтаксических структур, использованных для передачи политических нюансов. В исследовании применялся критический дискурс-анализ (КДА), опирающийся на трехмерную аналитическую парадигму Фэйрклафа (Fairclough 2010), с целью исследовать отношения дискурса и власти в речи Рухани, с одной стороны, и социально-культурные, религиозные и политические ценности, лежащие в основе риторических средств - с другой. Результаты показали, что политический дискурс Рухани включает различные риторические и дискурсивные средства, такие как трехчленные конструкции, повторения в параллельных конструкциях, аллитерацию и метафоры, влияющие на общественное мнение. Более того, использование кратких и лаконичных тезисов, визуальных символов и динамических метафор помогло ему обратиться к публике с высокой долей эмоциональности и привлечь значительный электорат.
\end{abstract}

Ключевые слова: риторические средства, критический дискурс-анализ (КДА), политический дискурс, президентская избирательная кампания

\section{История статьи:}

Дата поступления в редакцию: 05 сентября 2016

Дата принятия к печати: 18 ноября 2016

\section{Для цитирования:}

Azizullah Mirzaei, Zohreh R. Eslami, Fatemeh Safari. Exploring Rhetorical-Discursive Practices of Rouhani's Presidential Campaign and Victory of his Prudence-and-Hope Key: a Discourse of Persuasion // Вестник Российского университета дружбы народов. Серия: Лингвистика. 2017. T. 21. № 1. C. 161-182.

\section{Сведения об авторах:}

Азизулла Мирзаи, доктор, доцент кафедры прикладной лингвистики факультета английского языка, Университет Шахре-Корд (Иран). Сфера научных интересов: прагматика, теория дискурса, дискурс анализ, межкультурная коммуникация. Контактная информация: e-mail: fazizullah@yahoo.com 
Зохрэ Еслами, доктор, профессор кафедры преподавания, изучения языков и культур, Техасский университет А\&M в Катаре (Катар). Сфера научных интересов: межкультурная прагматика, теория дискурса, дискурс анализ, межкультурная коммуникация, методика преподавания второго иностранного языка, формирование культурных компетенций в рамках изучения иностранного языка. Контактная информация: e-mail: zeslami@tamu.edu

Фатима Сафари, аспирант кафедры прикладной лингвистики факультета английского языка, Университет Шахре-Корд (Иран). Сфера научных интересов: прагматика, теория дискурса, дискурс анализ, межкультурная коммуникация, vметодика преподавания второго иностранного языка. Контактная информация: e-mail: f_19safari@yahoo.com 